\title{
Plant-made vaccines in support of the Millennium Development Goals
}

\author{
Claire A. Penney $\cdot$ David R. Thomas • \\ Sadia S. Deen • Amanda M. Walmsley
}

Received: 16 November 2010/Revised: 23 December 2010/Accepted: 24 December 2010/Published online: 18 January 2011

(C) The Author(s) 2011. This article is published with open access at Springerlink.com

\begin{abstract}
Vaccines are one of the most successful public health achievements of the last century. Systematic immunisation programs have reduced the burden of infectious diseases on a global scale. However, there are limitations to the current technology, which often requires costly infrastructure and long lead times for production. Furthermore, the requirement to keep vaccines within the cold-chain throughout manufacture, transport and storage is often impractical and prohibitively expensive in developing countries - the very regions where vaccines are most needed. In contrast, plant-made vaccines (PMVs) can be produced at a lower cost using basic greenhouse agricultural methods, and do not need to be kept within such narrow temperature ranges. This increases the feasibility of developing countries producing vaccines locally at a smallscale to target the specific needs of the region. Additionally, the ability of plant-production technologies to rapidly
\end{abstract}

Communicated by R. Reski.

Claire A. Penney and David R. Thomas contributed equally to this work.

A contribution to the Special Issue: Plant Biotechnology in Support of the Millennium Development Goals.

C. A. Penney - D. R. Thomas · S. S. Deen ·

A. M. Walmsley $(\bowtie)$

Department of Biological Sciences, Monash University,

Clayton, VIC, Australia

e-mail: amanda.walmsley@monash.edu

C. A. Penney

e-mail: claire.penney@monash.edu

D. R. Thomas

e-mail: david.r.thomas@monash.edu

S. S. Deen

e-mail: sadia.deen@monash.edu produce large quantities of strain-specific vaccine demonstrates their potential use in combating pandemics. PMVs are a proven technology that has the potential to play an important role in increasing global health, both in the context of the 2015 Millennium Development Goals and beyond.

Keywords Millennium Development Goals ·

Plant-made vaccine Thermo-stability - Orphan vaccine . Pandemic · Transgenic

\section{Introduction}

At the 2000 UN Millennium Summit, world leaders committed to addressing the Millennium Development Goals, aimed at improving social and economic conditions in developing countries. The eight goals cover various issues associated with poverty, education, health and sustainable development. Plant-made vaccines (PMVs) have the ability to directly address the health-related goals, specifically the targeted reductions in incidence of major diseases, and of child mortality due to preventable diseases such as cholera and enterotoxigenic Escherichia coli.

Plant molecular biology and biotechnology have enhanced and expanded the medicinal applications of plants in many ways. Plants can be engineered to act as bioreactors for vaccine and therapeutic production, and their metabolic pathways can be manipulated to increase compounds of benefit or decrease detrimental compounds. While some of these activities can be achieved through mutagenesis and traditional plant breeding, the most direct and exacting path is through genetic modification or transformation of plant cells. Expressing recombinant proteins in transgenic plants has been actively researched for the past 20 years, resulting 
in a fast and flexible production system. The knowledge, tools and techniques have been steadily building, and have now reached the point where commercial production of biopharmaceuticals by transgenic plants is a certainty.

\section{Plants as protein production systems}

\section{Methods of transgene expression}

The ability of transgenic plants to produce complex proteins using low-grade technology makes them a powerful tool for recombinant protein production. Proteins can be produced through either stable or transient expression of transgenes. Stable production systems involve the insertion of a foreign gene into the genome of a host plant resulting in the maintenance of the foreign gene in the host's genetic lineage over multiple generations. In contrast, transient systems use bacterial or viral vectors to insert transgenes into a host cell. The foreign gene or transgene is then expressed for a relatively brief timespan. Until recently, PMVs were plagued by concerns regarding low antigen yields, regulatory issues around transgene containment, and the potential for gene silencing to dramatically reduce antigen yield. While this has slowed the commercial development of the technology, much progress has been made through various avenues of research. Recombinant protein yields have been greatly increased in stable systems though subcellular targeting and chloroplast transformation, with levels of up to $46 \%$ of total soluble protein (TSP) being reported (Sharma and Sharma 2009). It has been estimated that through the use of chloroplast genetic engineering, 1 acre of tobacco expressing a protective antigen from anthrax could produce up to 360 million doses of anthrax vaccine (Koya et al. 2005). This approach has the benefits of negating gene silencing as it rarely occurs in chloroplasts, and also provides a mechanism for gene containment, as chloroplasts are maternally inherited (Ruf et al. 2007).

Another commonly used method to increase protein accumulation and avoid gene silencing is through the use of transient expression (Kapila et al. 1997; Komarova et al. 2010). A recently described transient expression system, 'magnifection' (Gleba et al. 2005; Marillonnet et al. 2005), has been demonstrated to rapidly produce clinically relevant levels of a personalised therapeutic vaccine against non-Hodgkin's lymphoma in Nicotiana benthamiana (Bendandi et al. 2010). This system has been shown to result in a recombinant protein yield of up to $80 \%$ TSP (Marillonnet et al. 2004), and it has been predicted that this could result in vaccines produced for less than 0.01 USD per $0.1 \mathrm{mg}$ dose (Gleba et al. 2005). There are several transient expression systems based on deconstructed viruses, and it is not uncommon for yields to approach or better $1 \mathrm{~g} / \mathrm{kg}$ (Komarova et al. 2010). However, viral systems suffer from several drawbacks, including size restrictions on the gene being expressed, issues of biocontainment, and difficulties associated with expressing more than one protein at a time. In order to overcome these hurdles, another system has been designed, based on a disabled version of Cowpea mosaic virus RNA-2. This has resulted in levels of foreign protein accumulation up to 20\% TSP (Sainsbury and Lomonossoff 2008).

\section{Purification}

The major cost of producing purified proteins such as subunit vaccines is contained in the separation and purification steps, which can account for up to $90 \%$ of total production costs (Cunha and Aires-Barros 2002). A benefit of plant-based expression systems is that they allow for alternative purification methods, such as elastin-like polypeptide (ELP) fusion technology. ELPs exhibit the unique characteristic of reversible phase transition, meaning they can be precipitated out of solution and re-suspended again through temperature manipulation. The addition of ELPs to a protein of interest allows it to be collected and separated from host proteins via centrifugation of crude extracts (Floss et al. 2010). Other purification methods include the use of hydrophobin tags to produce protein bodies within the plant tissue, and oleosin tags to produce oil bodies. These can be separated to varying purities from crude protein extracts based on their density (Capuano et al. 2007; Joensuu et al. 2010).

\section{Progress to market}

To date, no PMV has made it onto the market. With no clear precedent, there have been concerns regarding the commercial feasibility of the technology. However, in recent years multiple companies have progressed through to Phase II and III trials (Faye and Gomord 2010), forcing regulatory agencies to become involved. For example, ORF Genetics produces several growth factors in stably transformed barley for use in the cosmetic industry (ORF Genetics 2010). Protalix BioTherapeutics has just completed a Phase III trial for taliglucerase alfa produced in stable carrot cell cultures. Used to treat Gaucher disease, the product was approved by the U.S Food and Drug Administration (FDA), who have since accepted a New Drug Application and granted a Prescription Drug User Fee Act action date in early 2011 (Protalix BioTherapeutics 2010). SemBioSys have completed Phase II trials of insulin produced in transgenic safflower, and have filed an Investigational New Drug Application with the FDA, and submitted a Clinical Trial Application to European authorities 
(SemBioSys 2009). Medicago are currently undergoing Phase II trials for their avian influenza vaccine produced transiently in tobacco, after receiving clearance from Health Canada (Medicago 2010). It must be noted that all the above examples are purified proteins, and with no set precedent the path for unpurified PMVs remains unclear.

\section{The need for thermo-stable vaccines}

\section{Current requirement for the vaccine cold-chain}

Every year, millions of children die from vaccine-preventable diseases. While vaccines are one of the greatest success stories in modern medicine, and one of the most cost-effective public health measures available, more can be done to allow vaccines to reach their full potential (Frieden and Henning 2009). Due to time and distance barriers between the point of manufacture and points of use, uncertainty often arises as to whether the vaccine in question has been maintained under conditions that preserve effectiveness. This problem is compounded by the fact that there is no easy and inexpensive test to settle this uncertainty. As such, one greatly desired trait is the ability to easily test vaccine potency, or better yet, for the vaccine to be able to withstand wide temperature ranges before any potency is lost. Many vaccines are sensitive to heat and freezing, and as a result are often damaged though poor temperature maintenance (Atkinson et al. 2002; Wirkas et al. 2007). The temperature limitations of vaccines are currently minimised through the use of the cold-chain, a process in which products are kept within a defined, often refrigerated, temperature range from manufacture through to distribution and storage (Weir and Hatch 2004). The system is far from ideal, as the cost of maintaining the cold-chain has been estimated at between 200 and 300 million USD annually (Das 2004), and there is little guarantee that the chain will not be broken (Berhane and Demissie 2000). As well as issues regarding practicality, the affordability of a vaccine is a primary determinate of its sustainable use in developing countries. The use of thermostable vaccines would eliminate the need for the costly cold-chain process, increase confidence in vaccine efficacy, and release funds that would enable the vaccination of more individuals.

\section{Thermo-stability of PMVs}

Plant-based production systems offer a platform for the manufacture of heat-stable recombinant proteins (Stöger et al. 2000). This can be achieved by expressing the vaccine antigen in a plant storage body such as the seed or tuber or within plant vegetative tissues or fruits. Harvested material is processed through freeze-drying, crushing or powdering, and pooled to produce a thermo-stable vaccine batch that can be conveniently transported and stored at ambient temperatures (Zhang et al. 2006). The plant seed has emerged as one of the preferred plant storage organs for vaccine antigen accumulation, with the current leading platforms being rice and maize (Lau and Sun 2009). Unlike in vegetative plant tissue, seed storage proteins are sequestered within protein bodies, specialised vacuoles in the mature seed that have low protease levels (Müntz 1998). Recombinant proteins have been demonstrated to accumulate at high levels in seeds, and have been demonstrated to remain stable and immunogenic in both animals and humans for over 18 months when stored without refrigeration (Chikwamba et al. 2002; Lamphear et al. 2002; Nochi et al. 2007).

Cholera is a major killer in developing countries, and the recent outbreak during the Pakistan floods resulted in an estimated 300,000 cases of acute diarrhoea (Enserink 2010). Freeze-drying tomatoes expressing subunit B from the heat-labile enterotoxin secreted by enterotoxigenic E. coli (LTB) has been shown to result in LTB fusion proteins that are stable at room temperature for over 5 months (Walmsley et al. 2003). LTB has been proposed as a vaccine candidate for cholera, as it is very similar in structure to the cholera antigen CTB, and there is a high-level of immunological cross-reactivity between these proteins (Svennerholm et al. 1986). Oral immunisation with powdered transgenic rice expressing CTB (MucoRice-CTB) has been shown to prevent diarrhoea in mice following challenge with Vibrio cholerae and enterotoxigenic E. coli (Tokuhara et al. 2010). Importantly, rice that had been stored for over 3 years at ambient temperature was demonstrated to induce neutralising antibodies at a level comparable to freshly harvested material. The ability of this vaccine to be stored without refrigeration in developing countries that suffer from regular cholera outbreaks is of huge benefit. As evidenced by recent events in Haiti, pandemic outbreaks of diseases such as cholera are often triggered by natural disasters, and are therefore often associated with electricity shortages disrupting the coldchain. The thermo-stability of PMVs offer a definite gain over the current cholera vaccine leader (Dukoral, SBL Vaccines, Sweden), which has a shelf life of 3 years only when stored at $2-8^{\circ} \mathrm{C}$ (Galazka et al. 2006).

The ability to store and stockpile vaccines is crucial in preparation for pandemics, as it allows for vaccination campaigns to be undertaken at an early stage, mitigating the impact of the disease. Yersinia pestis, the cause of pneumonic, septicemic, and bubonic plague, is estimated to cause between 1000 and 5000 cases per year (Stenseth et al. 2008). Recent outbreaks include India in 1994 and the Democratic Republic of the Congo in 2006. It is unlikely to 
ever be completely eliminated, as it is widespread in the wildlife, with rodents acting as reservoirs (Gratz 1999). While there is a vaccine available, it confers limited protection from the pneumonic form, requires multiple boosters, and is associated with various side effects (Bramwell et al. 2005). To address this issue, an orally delivered booster vaccine consisting of a F1-V fusion protein was expressed in tomatoes (Alvarez et al. 2006). The fruits were freeze-dried, powdered and pooled, and after being stored at room temperature immunogenicity was confirmed in mice. In another study, the F1-V fusion was expressed in lettuce. This was found to be stable in freeze-dried material for up to 6 months at $25^{\circ} \mathrm{C}$, and was immunogenic when used as a sub-cutaneous primer and oral booster (Rosales-Mendoza et al. 2010).

When stored at $2-8^{\circ} \mathrm{C}$ as a freeze-dried powder, the current live, attenuated measles vaccine is stable for up to 2 years (Galazka et al. 2006). However, when stored at $20-25^{\circ} \mathrm{C}$ for 6 months, only one-third of vaccine activity remains, and when stored at $36-38^{\circ} \mathrm{C}$, a similar decrease is seen in just 3 weeks. When exposed to temperatures of $54-56^{\circ} \mathrm{C}$, this drop takes only $12 \mathrm{~h}$ (Galazka et al. 2006; McAleer et al. 1980). A subunit measles PMV consisting of the measles virus hemagglutinin protein expressed in lettuce was found to be immunogenic in mice, and showed no loss of vaccine content when freeze-dried material was stored at room temperature for 7 months (Webster et al. 2006). Further, the vaccine could be stored at $50^{\circ} \mathrm{C}$ for 1 week without any observable loss of antigen content. Loss was only detected when the plant material was stored at $70^{\circ} \mathrm{C}$ for 1 week. Freeze-drying the material also resulted in a 20 -fold increase in antigen concentration, reducing the physical amount of material required to administer each dose. In another study by the same group, a malaria vaccine consisting of the surface protein PyMSP4/5 from Plasmodium yoelii expressed in the leaves of $N$. benthamiana was found to be immunogenic in mice and stable for at least 2 years when stored at ambient temperatures (Webster et al. 2009).

\section{Rapid production of vaccines in response to emerging pandemics}

The surge potential of PMVs

Controlling an emerging pandemic requires a swift and aggressive response. New vaccine production systems are needed to provide greater flexibility and surge potential. The proven ability of plant-production systems to rapidly respond to newly emerging threats demonstrates their potential to fill this niche (D'Aoust et al. 2010). The technology for transient expression in tobacco has been well documented and optimised, and a number of recombinant proteins have been successfully produced (Tremblay et al. 2010). Importantly for vaccine production, the species has a high biomass, with intensive cultivation producing up to 170 metric tonnes per hectare (Schillberg et al. 2003). Low-alkaloid varieties can be used for oral vaccine delivery, in order to mitigate the potential effects of metabolites (Menassa et al. 2007). The development of automated vacuum-agroinfiltration systems means that large numbers of tobacco plants can now be rapidly infiltrated (Fischer et al. 2004; Gleba et al. 2005) (Fig. 1). This technology allows for bulk vaccine production within 3-10 days of the transgene vector becoming available (Fig. 2). This is in stark contrast with stable plant transformation systems, which have a minimum lead-time of several months. The flexibility and speed of transient expression systems also allows for rapid testing of different genetic constructs without waiting for plants to be stably transformed, selected and grown.

\section{Current influenza vaccines}

Influenza pandemics are unpredictable events that have been recurring at regular intervals since at least the sixteenth century (Ghendon 1994). There is no way to accurately predict the probability of an influenza pandemic occurring, and there is uncertainty regarding the type and severity of a future pandemic strain (Smith et al. 2009). As a result, the

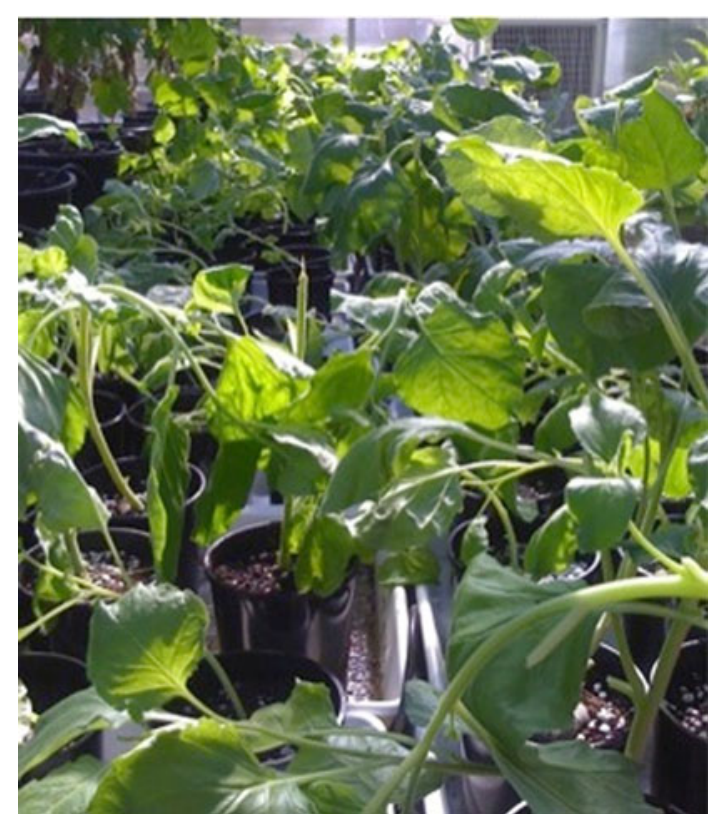

Fig. 1 Nicotiana benthamiana plants transiently expressing LTB after vacuum-agroinfiltration. Using this method, it is possible to sustainably produce $2 \mathrm{~g}$ of recombinant vaccine per square metre annually 
best way to respond to a pandemic is through large-scale rapid production and delivery of a strain-specific vaccine (WHO 2006). Currently, the majority of influenza vaccines are produced in fertile hen eggs using the prevalent influenza strains, as determined biannually by the WHO Global Influenza Surveillance Network (Barr et al. 2010). The eggs are infected with a recombinant version of the virus, which is allowed to grow in the egg before being extracted, purified, and treated to separate the egg proteins from the viral particles. Approximately one to two eggs are required per pandemic vaccine dose (Neuzil and Bright 2009).

While the egg-based production method is well established and cost-effective, there are disadvantages. It is a relatively lengthy process (5-6 months from the determination of vaccine strains to vaccine release), resulting in a significant lag time between the beginning of a pandemic and the release of a viable vaccine in large numbers (Gerdil 2003) (Fig. 2). Egg-based production of the H1N1 vaccine in 2009 was hindered by low yields, with production being only half of what was originally predicted (Singh et al. 2010; Zoler 2009). Fortunately, issues regarding seasonal availability of eggs have been somewhat overcome due to recent funding initiatives targeting year-round egg supplies in developed and developing countries (Partridge et al. 2010). However, unexpected poor yield can create a bottleneck in vaccine production for pandemic preparedness. Furthermore, the supply of fertile eggs can be at risk from the spread of avian influenza (Webby and Webster 2003), and long lead-times for vaccine development and production means that a midcourse change in the vaccine produced is not feasible. This is of particular importance to pandemic influenza preparedness, as potential supply is expected to fall short of global needs by several billion doses (Kieny et al. 2006). Under pandemic conditions it has been predicted that few vaccine doses will be available for

\section{COMPARISON OF ESTIMATED TIMELINES FOR PLANT-BASED} AND EGG-BASED VACCINE PRODUCTION

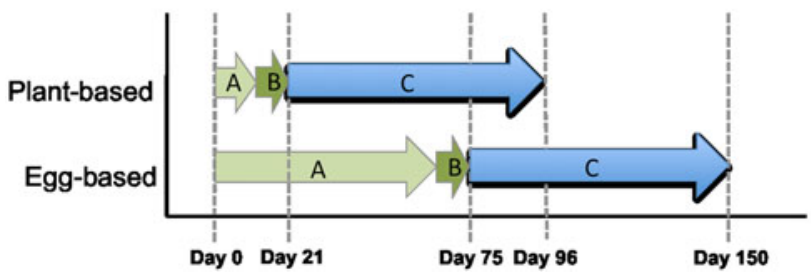

Fig. 2 Comparison of plant-made (D'Aoust et al. 2010) and eggbased (WHO 2009) influenza vaccine production timelines. Transient plant-based production can potentially reduce the time from target identification to vaccine release by over one third. Day 0: Target strain identified. A Pre-production, (cloning and transformation of Agrobacterium for plants, preparation of vaccine strain for egg-based system). $B$ Production time for first batch. $C$ Estimated 2.5 months for testing and regulatory approval populations outside of the manufacturing countries (Fedson and Dunnill 2007). The superior financial resources of developed nations are likely to ensure first access to influenza vaccine capacity in the event of a pandemic outbreak (PATH and Oliver Wyman 2007) leading to the estimate that developing countries will account for $96 \%$ of deaths resulting from a pandemic influenza outbreak (Murray et al. 2006).

\section{PMVs for influenza}

Seasonal influenza epidemics result in three to five million cases of severe illness worldwide each year, and up to 500,000 deaths (Carrat and Flahault 2007). Vaccines cannot be stored from one influenza season to the next, as strains change from year to year. This stands in marked contrast to vaccines against infectious diseases, that do not exhibit strain variation, as these can be mass-produced and stock-piled in preparation. In order to protect at-risk groups during influenza season, it is important that seasonal vaccine production is not compromised to focus exclusively on pandemic production. A new rapid, flexible production system is required to adequately protect against both seasonal and epidemic influenza outbreaks. The ability of plants to act as quick response systems was recently proven by D'Aoust and colleagues at Medicago (D'Aoust et al. 2008, 2010). Agrobacterium-mediated, transient expression of haemagglutinin (HA) from multiple strains of influenza was performed in N. benthamiana (D'Aoust et al. 2008). The transiently expressing plants produced large amounts of HA (50 mg/kg) from H5N1 (avian influenza virus) and H1N1 (human) strains. HA was shown to assemble as virus-like particles (VLPs), highly organised non-infectious particles formed through the self-assembly of viral structural proteins. VLPs physically mimic live viruses and have been demonstrated to induce robust humoral and cellular immune responses (Grgacic and Anderson 2006). The highlight of this research was that the purified vaccine was produced within 3 weeks of the release of viral sequence. Animal studies confirmed the efficacy and safety of this vaccine. Mice immunised intramuscularly with two doses of $0.5 \mu \mathrm{g}$ of the purified H5-VLPs were protected against H5N1 influenza virus challenge (D'Aoust et al. 2008). The rapid nature of this platform enables plant-based production facilities to be normally used for other recombinant protein products, and if a pandemic emerged, the plant facility could rapidly design an appropriate vaccine and switch manufacture.

Cost of facilities

The cost of building a Good Manufacturing Practice (GMP)-compliant facility that could produce $100 \mathrm{~kg}$ of 
vaccine in $N$. benthamiana annually (enough for one billion $0.1 \mathrm{mg}$ doses), has been estimated to be under 15 million USD, and after this initial outlay upkeep costs are minimal (Gleba et al. 2005).The plant-production system is a more affordable option than many current vaccine production systems that routinely cost in the hundreds of millions of dollars to start and maintain. Further, the plant-based system can produce number of vaccine doses unable to be matched by current facilities. In comparison to the plantmade, one billion doses for 15 million USD, Sanofi Pasteur is a traditional vaccine production facility in Pennsylvania, USA that can produce 100 million influenza vaccine doses per year at a cost of 150 million USD (Sanofi Pasteur 2009). Even more costly is Novartis' new cell culture facility in North Carolina, USA. This new facility will cost almost one billion USD in investments with an expected 300 million doses of vaccine produced per year (Novartis 2009).

\section{PMVs in developing countries}

\section{Orphan diseases}

The distribution of disease burden is not uniform throughout the world. Much of the impact is felt disproportionally in developing countries, where health care and sanitation programs are limited. There are also diseases that are geographically restricted, such as the parasitic Chagas disease whose 10-12 million sufferers are almost all from Central and South America, and Onchocerciases, of which $99 \%$ of an estimated 18 million cases occur in sub-Saharan Africa (Hotez and Ferris 2006). Due to the poor potential market for vaccines for these diseases, manufacturers often overlook them, and for this reason they earn the name of orphan diseases (Trouiller et al. 2002). However, for the countries affected, orphan diseases can actually offer the greatest return on investments in disease control (Boutayeb 2010). It is therefore of great benefit for countries to be able to cheaply and easily produce vaccines tailored to the local conditions and strains, as well as easily distribute them to remote regions. Providing proper regulatory oversight exists to ensure that GMP is established and maintained, PMVs can be produced cheaply and locally on small scales using basic technology. As well as immediate effects such as easing the strain on health services caused by preventable disease, constant local production could allow countries to initiate eradication programs through maintainable vaccination schedules. This would be particularly effective against diseases that present stable vaccine targets with low mutation rates.
Hidden costs of traditional vaccines

The aforementioned cost of the cold-chain greatly strains the resources of developing nations. In addition, injected vaccines carry the cost of needles and safe disposal methods, and require trained staff for administration. While the purchase cost of the syringe is in itself low, there is an associated risk of iatrogenic disease (Giudice and Campbell 2006). When the societal cost of spread of blood-borne pathogens (for example, HIV and hepatitis B) through the reuse or inappropriate disposal of needles is included into the analysis, the cost of needle delivery through standard disposable syringes escalates from 0.10 to 25.29 USD per delivery (Ekwueme et al. 2002). Auto-disabling (AD) needles are now the most common delivery system and have a total cost of only 0.91 USD, although the cost of the device is originally more expensive at 0.14 USD each (Ekwueme et al. 2002). The main reason for this usage shift is the donation of AD needles by GAVI, WHO, UNICEF and other agencies. As low-middle income countries are not eligible for assistance, they still have low AD use (Levin et al. 2010), which correlates strongly to the incidence of HIV (Deuchert and Brody 2007). In contrast, oral delivery of PMVs can sidestep these problems. Besides being highly stable, the fact that plants are a regular part of the human diet means that only minimal down-stream processing of material is necessary. It is hypothesised that the plant cell wall protects the antigen from digestion before it is taken up to induce an immune response (Sala et al. 2003). It must be stressed, however, that much research is yet required to reduce the variability of immune responses, and to ensure the safety of PMVs for oral vaccination.

\section{Regulatory hurdles}

There are regulatory issues for PMVs to overcome beyond the approval process, as there is the risk that seeds or pollen from stably transformed plants could escape containment and become included within food crops or the wild population. This leads to concerns regarding oral tolerance of the vaccine (Kirk et al. 2005; Ling et al. 2010). Oral tolerance is a form of peripheral tolerance through which external agents such as dietary proteins and commensal bacteria that gain access to the body through a natural route are recognised as non-harmful and do not induce potentially harmful local or systemic immune responses (Faria and Weiner 2005). Oral tolerance can occur if the antigen is administered too frequently, or at too high or too low a dose (Gregerson et al. 1993). It is not yet widely understood, although it is proposed that it could be counteracted by high levels of antigen accumulation in the plant, as this will reduce the level of tolerance induced by the plant 
tissue for a given antigen dose (Kostrzak et al. 2009). Potential oral PMVs will need to be assessed on a case-bycase basis to ensure that the antigen formulation, dose size, and immunisation protocols strike a balance between immune response and oral tolerance. It is also almost certain that any plants grown to produce vaccines will have to be done under GMP in physically enclosed greenhouses. While there are several molecular methods for gene containment, such as terminator genes or plastid engineering, none of these can achieve 100\% containment (Murphy 2007), which over a period of time can represent a significance likelihood of escape (Lee and Natesan 2006).

\section{Local production of PMVs}

There is an important niche that can be filled by low-cost PMVs, and the technology is advancing to the point where it can meet the requirements to be successfully employed. While transient expression often yields higher antigen levels than stably transformed plants (Daniell et al. 2009), the additional purification and production costs required would likely be beyond what many poorer regions can feasibly spend. The advantages of being able to grow stably transformed plants with local technology, and to orally vaccinate using minimally purified plant-made material makes transgenic plants a desirable system for developing countries.

After the plants have been grown and contained in greenhouses, the path from raw biomass to oral vaccine is relatively straightforward. The plant material is harvested and freeze-dried, although this step can be potentially replaced by air-drying in some cases (Zhang et al. 2006). The dried material is then powdered to form batches, and samples can be taken to analyse antigen content and detect any potential toxins. While this step may require more specialised equipment and training, it can easily be undertaken offsite, with samples being sent to universities or biotechnology companies. Once the dosage has been determined, the required amount of plant material can be delivered under supervision as a paste, capsule or suspension (Hefferon 2010).

The cost of vaccine production in tomatoes has been estimated by Kirk and Webb (2005) for a one-hectare greenhouse. Assuming a required dose of $1 \mathrm{mg}$ of vaccine, and expression levels of 20 and $40 \mu \mathrm{g} / \mathrm{g}$ fresh weight, the cost to grow and freeze-dry a vaccine batch works out at 22.8 and 11.4 US cents per dose, respectively. If the level of expression can be increased, or the required dose decreased, it is possible to reduce the cost per dose to below 1 cent. Producing 10-20 million doses of vaccine in this way has been estimated to cost between 1.8 and 2.5 million USD per year. It must be noted that these estimates are highly simplified, and exclude many additional costs, such as packaging, labour, maintenance and supplies. The high cost of freeze-dryers is a major limiting factor, and highlights the need to increase expression levels and explore other avenues such as air-drying for preservation.

In reality, this high volume of material and vaccines is unlikely to be feasible for many developing regions where they would be of use. If smaller greenhouses were used, for example $100 \mathrm{~m}^{2}$, the associated costs would be greatly reduced, especially those associated with freeze-driers, as freeze-driers at this scale cost approximately 30,000 USD. The cost to build a greenhouse of this size is approximately 108,000 USD, assuming a cost of 100 USD per square foot (Kirk and Webb 2005). The lower volume also make handling a lot easier, as only about $100 \mathrm{~kg}$ of fruit would need to be processed per week, which when freeze-dried reduces to about $5 \mathrm{~kg}$. This amount of plant material can easily be ground in a bench top blender and mixed in large containers. From this mix, multiple samples can be taken for analysis of vaccine and contaminant content. The vaccine batch can then be formed into tablets or capsules, and distributed as needed. This method can produce around 104,000 doses per year at a cost of around 138,000 USD for the greenhouse and freeze dryer, resulting in a vaccine cost of 8.8 cents per dose over 15 years. As above, this estimate does not take into account other associated costs, although if yearly running costs are estimated at 10,000 USD the price per dose over 15 years increases to 18.5 cents. These expenses would likely be offset through the eliminated need for needles (thus saving on purchase, disposal, and the cost of trained staff) and cold storage (especially if the vaccine is transported between villages).

\section{Additional benefits of PMVs}

Localised production facilitates easier and cheaper distribution of vaccines doses, increasing overall coverage rates. As well as the direct effect of reducing disease burdens, vaccines produced in this way can also present broaderreaching benefits, such as increasing herd immunity. This can result in a significant increase in the reported health benefits of a vaccine (Jeuland et al. 2010; Lloyd et al. 2008). For example, it is estimated that $80-86 \%$ coverage of immunity would be sufficient to eliminate mumps, polio, rubella and smallpox from a population (Smith 2010). Herd immunity reduces the spread of disease between unvaccinated people, and also provides an extra degree of protection to those who have been vaccinated but had weaker immune responses. As it is quite common for the efficacy of vaccines to be much lower in developing regions, possibly due to reduced overall health or differences in strains (Madhi et al. 2010), an increase in herd immunity can provide a significant benefit. This will be most pronounced in areas where people live in close proximity to each other (Ali et al. 2005), as is often the case in developing countries. 


\section{Conclusion}

Research over the past 20 years has proven that plants are a flexible vaccine production system capable of expressing a broad range of different protective antigens that can be purified and delivered by injection and with evidence of feasibility of oral delivery. However, reaching the full potential of PMVs relies on effective delivery systems. While the most advanced PMVs are purified and only use plants as a production system, oral administration is considered the easiest means of delivery. The ease of administration can result in increased patient compliance and is highly compatible with immunisation schemes in developing nations. Before oral delivery of PMVs can become a reality, critical safety and regulatory issues concerning genetically modified organisms and pharmaceuticals will need to be addressed, most likely on a case-by-case basis.

While pessimism regarding the ability for the technology to be accepted and implemented by regulatory bodies remains, the accomplishments of PMVs should not be undervalued. Many of the hypothesised advantages have been realised, and many initial claims have been justified. PMVs have been produced and purified to a deliverable product in a timeframe suitable for responding to pandemics, where existing technologies fall short. Minimally processed plant material has been shown to be stable without the addition of any preservatives at time intervals and temperatures beyond the reach of current vaccines. This can facilitate vaccination in remote regions without the need for significant investment in infrastructure, as well as the stockpiling of vaccines in regions that are prone to disease outbreaks. Finally, the use of PMVs would allow governments to address specific problems such as orphan diseases and reduce their dependence on developed nations for vaccine supplies. Investigations now need to concentrate on improved delivery methods, specifically via mucosal routes, to enable the technology to reach its full potential and aid the areas of the world afflicted the most. PMVs are potentially powerful tools in the fight against disease, and if properly implemented could play a significant role in increasing global health, both in the scope of the 2015 Millennium Development Goals and beyond.

Open Access This article is distributed under the terms of the Creative Commons Attribution Noncommercial License which permits any noncommercial use, distribution, and reproduction in any medium, provided the original author(s) and source are credited.

\section{References}

Ali M, Emch M, Vonseidlein L, Yunus M, Sack D, Rao M, Holmgren J, Clemens J (2005) Herd immunity conferred by killed oral cholera vaccines in Bangladesh: a reanalysis. Lancet 366:44-49
Alvarez ML, Pinyerd HL, Crisantes JD, Rigano MM, Pinkhasov J, Walmsley AM, Mason HS, Cardineau GA (2006) Plant-made subunit vaccine against pneumonic and bubonic plague is orally immunogenic in mice. Vaccine 24:2477-2490

Atkinson WL, Pickering LK, Schwartz B, Weniger BG, Iskander JK, Watson JC (2002) General recommendations on immunization. Recommendations of the Advisory Committee on Immunization Practices (ACIP) and the American Academy of Family Physicians (AAFP). MMWR Recomm Rep 51:1-36

Barr IG, McCauley J, Cox N, Daniels R, Engelhardt OG, Fukuda K, Grohmann G, Hay A, Kelso A, Klimov A, Odagiri T, Smith D, Russell C, Tashiro M, Webby R, Wood J, Ye Z, Zhang W; Writing Committee of the WHO Consultation on Northern Hemisphere Influenza Vaccine Composition for 2009-2010 (2010) Epidemiological, antigenic and genetic characteristics of seasonal influenza A (H1N1) and B influenza viruses: basis for the WHO recommendation on the composition of influenza vaccines for use in the 2009-2010 Northern Hemisphere season. Vaccine 5:1156-1167

Bendandi M, Marillonnet S, Kandzia R, Thieme F, Nickstadt A, Herz $\mathrm{S}$, Fröde $\mathrm{R}$, Inogés $\mathrm{S}$, Lòpez-Dìaz de Cerio A, Soria $\mathrm{E}$, Villanueva H, Vancanneyt G, McCormick A, Tusé D, Lenz J, Butler-Ransohoff J-E, Klimyuk V, Gleba Y (2010) Rapid, highyield production in plants of individualized idiotype vaccines for non-Hodgkin's lymphoma. Ann Oncol 21:2420-2427

Berhane Y, Demissie M (2000) Cold chain at immunization centres in Ethiopia. East Afr Med J 77:476-479

Boutayeb A (2010) The burden of neglected countries. In: Preedy VR, Watson RR (eds) Handbook of disease burdens and quality of life. Springer, New York, pp 517-529

Bramwell VW, Eyles JE, OyaAlpar H (2005) Particulate delivery systems for biodefense subunit vaccines. Adv Drug Deliv Rev 57:1247-1265

Capuano F, Beaudoin F, Napier JA, Shewry PR (2007) Properties and exploitation of oleosins. Biotechnol Adv 25:203-206

Carrat F, Flahault A (2007) Influenza vaccine: the challenge of antigenic drift. Vaccine 25:6852-6862

Chikwamba R, Cunnick J, Hathaway D, McMurray J, Mason H, Wang K (2002) A functional antigen in a practical crop: LT-B producing maize protects mice against Escherichia coli heat labile enterotoxin (LT) and cholera toxin (CT). Transgenic Res 11:479-493

Cunha T, Aires-Barros R (2002) Large-scale extraction of proteins. Mol Biotechnol 20:29-40

D'Aoust M-A, Lavoie P-O, Couture MM-J, Trépanier S, Guay J-M, Dargis M, Mongrand S, Landry N, Ward BJ, Vézina L-P (2008) Influenza virus-like particles produced by transient expression in Nicotiana benthamiana induce a protective immune response against a lethal viral challenge in mice. Plant Biotechnol $\mathbf{J}$ 6:930-940

D’Aoust M-A, Couture MM-J, Charland N, Trépanier S, Landry N, Ors F, Vézina L-P (2010) The production of hemagglutininbased virus-like particles in plants: a rapid, efficient and safe response to pandemic influenza. Plant Biotechnol J 8:607-619

Daniell H, Singh ND, Mason H, Streatfield SJ (2009) Plant-made vaccine antigens and biopharmaceuticals. Trends Plant Sci 14:669-679

Das P (2004) Revolutionary vaccine technology breaks the cold chain. Lancet Infect Dis 4:719

Deuchert E, Brody S (2007) Lack of autodisposable syringe use and health care indicators are associated with high HIV prevalence: an international ecologic analysis. Ann Epidemiol 17:199-207

Ekwueme DU, Weniger BG, Chen RT (2002) Model-based estimates of risks of disease transmission and economic costs of seven injection devices in sub-Saharan Africa. Bull World Health Organ 80:859-870 
Enserink M (2010) No vaccines in the time of cholera. Science 329:1462

Faria AM, Weiner HL (2005) Oral tolerance. Immunol Rev 206:232-259

Faye L, Gomord V (2010) Success stories in molecular farming-a brief overview. Plant Biotechnol J 8:525-528

Fedson D, Dunnill P (2007) From scarcity to abundance: pandemic vaccines and other agents for "have not" countries. J Public Health Policy 28:322-340

Fischer R, Stoger E, Schillberg S, Christou P, Twyman RM (2004) Plant-based production of biopharmaceuticals. Curr Opin Plant Biol 7:152-158

Floss DM, Schallau K, Rose-John S, Conrad U, Scheller J (2010) Elastin-like polypeptides revolutionize protein expression and their biomedical application. Trends Biotechnol 28:37-45

Frieden TR, Henning KJ (2009) Public health requirements for rapid progress in global health. Global Public Health 4:323-337

Galazka A, Milstein J, Kartoglu U, Zaffran M (2006) Temperature sensitivity of vaccines, WHO. www.who.int/vaccines-documents/

Gerdil C (2003) The annual production cycle for influenza vaccine. Vaccine 21:1776-1779

Ghendon Y (1994) Introduction to pandemic influenza through history. Eur J Epidemiol 10:451-453

Giudice EL, Campbell JD (2006) Needle-free vaccine delivery. Adv Drug Deliv Rev 58:68-89

Gleba Y, Klimyuk V, Marillonnet S (2005) Magnifection-a new platform for expressing recombinant vaccines in plants. Vaccine 23:2042-2048

Gratz NG (1999) Emerging and resurging vector-borne diseases. Annu Rev Entomol 44:51-75

Gregerson DS, Obritsch WF, Donoso LA (1993) Oral tolerance in experimental autoimmune uveoretinitis. Direct mechanisms of resistance are induced by low dose vs. high dose feeding protocols. J Immunol 151:5751-5761

Grgacic EVL, Anderson DA (2006) Virus-like particles: passport to immune recognition. Methods 40:60-65

Hefferon KL (2010) The mucosal immune response to plant-derived vaccines. Pharm Res 27:2040-2042

Hotez PJ, Ferris MT (2006) The antipoverty vaccines. Vaccine 24:5787-5799

Jeuland M, Maskery B, Cook J, Poulos C, Clemens J, Lauria D, Stewart J, Lucas M, Whittington D (2010) Incorporating cholera vaccine herd protection into economic cost-benefit and costeffectiveness models. Procedia Vaccinol 2:140-146

Joensuu JJ, Conley AJ, Lienemann M, Brandle JE, Linder MB, Menassa R (2010) Hydrophobin fusions for high-level transient protein expression and purification in Nicotiana benthamiana. Plant Physiol 152:622-633

Kapila J, De Rycke R, Van Montagu M, Angenon G (1997) An Agrobacterium-mediated transient gene expression system for intact leaves. Plant Sci 122:101-108

Kieny MP, Costa A, Hombach J, Carrasco P, Pervikov Y, Salisbury D, Greco M, Gust I, LaForce M, Franco-Paredes C, Santos JI, D'Hondt ED, Rimmelzwaan G, Karron R, Fukuda K (2006) A global pandemic influenza vaccine action plan. Vaccine 24:6367-6370

Kirk DD, Webb SR (2005) The next 15 years: taking plant-made vaccines beyond proof of concept. Immunol Cell Biol $83: 248-256$

Kirk DD, McIntosh K, Walmsley AM, Peterson AKD (2005) Risk analysis for plant-made vaccines. Transgenic Res 14:449-462

Komarova TV, Baschieri S, Donini M, Marusic C, Benvenuto E, Dorokhov YL (2010) Transient expression systems for plantderived biopharmaceuticals. Expert Rev Vaccines 9:859-876

Kostrzak A, Gonzalez MC, Guetard D, Nagaraju DB, Wain-Hobson S, Tepfer D, Pniewski T, Sala M (2009) Oral administration of low doses of plant-based HbsAg induced antigen-specific IgAs and IgGs in mice, without increasing levels of regulatory $\mathrm{T}$ cells. Vaccine 27:4798-4807

Koya V, Moayeri M, Leppla SH, Daniell H (2005) Plant-based vaccine: mice immunized with chloroplast-derived anthrax protective antigen survive anthrax lethal toxin challenge. Infect Immun 73:8266-8274

Lamphear BJ, Jilka JM, Kesl L, Welter M, Howard JA, Streatfield SJ (2002) A corn-based delivery system for animal vaccines: an oral transmissible gastroenteritis virus vaccine boosts lactogenic immunity in swine. Vaccine 22:2420-2424

Lau OS, Sun SSM (2009) Plant seeds as bioreactors for recombinant protein production. Biotechnol Adv 27:1015-1022

Lee D, Natesan E (2006) Evaluating genetic containment strategies for transgenic plants. Trends Biotechnol 24:109-114

Levin A, Fang A, Hansen PM, Pyle D, Dia O, Schwalbe N (2010) A global health partnership's use of time-limited support to catalyze health practice change: the case of GAVI's injection safety support. PLoS ONE 5:e12986

Ling H-Y, Pelosi A, Walmsley AM (2010) Current status of plantmade vaccines for veterinary purposes. Expert Rev Vaccines 9:971-982

Lloyd A, Patel N, Scott DA, Runge C, Claes C, Rose M (2008) Costeffectiveness of heptavalent conjugate pneumococcal vaccine (Prevenar) in Germany: considering a high-risk population and herd immunity effects. Eur J Health Econ 9:7-15

Madhi SA, Cunliffe NA, Steele D, Witte D, Kirsten M, Louw C, Ngwira B, Victor JC, Gillard PH, Cheuvart BB, Han HH, Neuzil KM (2010) Effect of human rotavirus vaccine on severe diarrhea in African infants. New Engl J Med 362:289-298

Marillonnet S, Giritch A, Gils M, Kandzia R, Klimyuk V, Gleba Y (2004) In planta engineering of viral RNA replicons: efficient assembly by recombination of DNA modules delivered by Agrobacterium. PNAS 101:6852-6857

Marillonnet S, Thoeringer C, Kandzia R, Klimyuk V, Gleba Y (2005) Systematic Agrobacterium tumefaciens-mediated transfection of viral replicons for efficient transient expression in plants. Nat Biotechnol 23:718-723

McAleer WJ, Markus HZ, McLean AA, Buynak EB, Hilleman MR (1980) Stability on storage at various temperatures of live measles, mumps and rubella virus vaccines in new stabilizer. J Biol Stand 8:281-287

Medicago (Nov 1, 2010) Medicago receives regulatory approval and commences Phase II clinical testing of its avian influenza vaccine. Press release. Retrieved 12 Dec 2010. http://www.medicago. com/English/news/News-Releases/News-ReleaseDetails/2010/ Medicago-Receives-Regulatory-Approval-and-CommencesPhase-II-Clinical-Testing-of-its-Avian-Influenza-Vaccine1123044/ default.aspx

Menassa R, Du C, Yin ZQ, Ma S, Poussier P, Brandle J, Jevnikar AM (2007) Therapeutic effectiveness of orally administered transgenic low-alkaloid tobacco expressing human interleukin-10 in a mouse model of colitis. Plant Biotechnol J 5:50-59

Müntz K (1998) Deposition of storage proteins. Plant Mol Biol 38:77-99

Murphy DJ (2007) Improving containment strategies in biopharming. Plant Biotechnol J 5:555-569

Murray CJL, Lopez AD, Chin B, Feehan D, Hill KH (2006) Estimation of potential global pandemic influenza mortality on the basis of vital registry data from the 1918-20 pandemic: a quantitative analysis. Lancet 368:2211-2218

Neuzil KM, Bright RA (2009) Influenza vaccine manufacture: keeping up with change. J Infect Dis 200:835-837

Nochi T, Takagi H, Yuki Y, Yang L, Masumura T, Mejima M, Nakanishi U, Matsumura A, Uozumi A, Hiroi T, Morita S, Tanaka K, Takaiwa F, Kiyono H (2007) Rice-based mucosal 
vaccine as a global strategy for cold-chain-and needle-free vaccination. PNAS 104:10986-10991

Novartis (Nov 24, 2009) Novartis inaugurates large-scale US based cellculture influenza vaccine manufacturing facility. Press release. Retrieved 12 Dec 2010. http://www.novartis.com/newsroom/ media-releases/en/2009/1356789.shtml

PATH, Oliver Wyman (2007) Influenza vaccine strategies for broad global access. http://www.path.org/files/VAC_infl_publ_rpt_1007.pdf

ORF Genetics (Nov 11, 2010) ORF Genetics launches DERMOkine ${ }^{\text {TM }}$ growth factors. Press release. Retrieved 12 Dec 2010. http://www. orfgenetics.com/News/Readmore/orfgeneticslaunchesdermokine growthfactors

Partridge J, Kieny MP, The World Health Organization (2010) Global production of seasonal and pandemic (H1N1) influenza vaccines in 2009-2010 and comparison with previous estimates and global action plan targets. Vaccine 28:4709-4712

Protalix BioTherapeutics (Nov 2, 2010) ProtalixBioTherapeutics announces preliminary top-line positive data from taliglucerasealfa switchover trial. Press release. Retrieved 12 Dec 2010. http://phx. corporate-ir.net/phoenix.zhtml?c=101161\&p=irol-newsArticle \& ID $=1490071 \&$ highlight $=$

Rosales-Mendoza S, Soria-Guerra RE, Moreno-Fierros L, AlpucheSolís AG, Martínez-González L, Korban SS (2010) Expression of an immunogenic F1-V fusion protein in lettuce as a plantbased vaccine against plague. Planta 232:409-416

Ruf S, Karcher D, Bock R (2007) Determining the transgene containment level provided by chloroplast transformation. PNAS USA 104:6998-7002

Sainsbury F, Lomonossoff GP (2008) Extremely high-level and rapid transient protein in plants without the use of viral replication. Plant Physiol 148:1212-1218

Sala F, Rigano MM, Barbante A, Basso B, Walmsley AM, Castiglione S (2003) Vaccine antigen production in transgenic plants: strategies, gene constructs and perspectives. Vaccine $21: 803-808$

Sanofi Pasteur (May 6, 2009) U.S. FDA licenses Sanofi Pasteur's new influenza vaccine manufacturing facilities. Press release. Retrieved 12 Dec 2010. http://en.sanofi-aventis.com/press/press_ releases/2009/ppc_25066.asp

Schillberg S, Fischer R, Emans N (2003) Molecular farming of recombinant antibodies in plants. Cell Mol Life Sci 60:433-445

SemBioSys (April 1, 2009) SemBioSys provides update on insulin program. Press release. Retrieved 12 Dec 2010. http://micro. newswire.ca/release.cgi? $r k e y=1704016279 \&$ view $=36078-0 \&$ Start $=30 \&$ htm $=0$

Sharma AK, Sharma MK (2009) Plants as bioreactors: recent developments and emerging opportunities. Biotechnol Adv 27:811-832

Singh N, Pandey A, Mittal SK (2010) Avian influenza pandemic preparedness: developing prepandemic and pandemic vaccines against a moving target. Expert Rev Mol Med 12:14

Smith PG (2010) Concepts of herd protection and immunity. Procedia Vaccinol 2:134-139

Smith GJD, Bahl J, Vijaykrishna D, Zhang J, Poon LLM, Chen H, Webster RG, Malik Peiris JS, Guan Yi (2009) Dating the emergence of pandemic influenza viruses. PNAS 106:1170911712
Stenseth NC, Atshabar BB, Begon M, Belmain SR, Bertherat E, Carniel E, Gage KL, Leirs H, Rahalison L (2008) Plague: past, present, and future. PLoS Med 5:e3

Stöger E, Vaquero C, Torres E, Sack M, Nicholson L, Drossard J, Williams S, Keen D, Perrin Y, Christou P, Fischer R (2000) Cereal crops as viable production and storage systems for pharmaceutical scFv antibodies. Plant Mol Biol 42:583-590

Svennerholm A-M, Wikström M, Lindblad M, Holmgren J (1986) Monoclonal antibodies against Escherichia coli heat-stable toxin (STa) and their use in a diagnostic ST ganglioside GM1Enzyme-Linked-Immunosorbent-Assay. J Clin Microbiol 24:585-590

Tokuhara D, Yuki Y, Nochi T, Kodama T, Mejima M, Kurokawa S, Takahashi Y, Nanno M, Nakanishi U, Takaiwa F, Honda T, Kiyono H (2010) Secretory IgA-mediated protection against $V$. cholerae and heat-labile enterotoxin-producing enterotoxigenic Escherichia coli by rice-based vaccine. PNAS USA 107:8794 8799

Tremblay R, Wang D, Jevnikar AM, Ma S (2010) Tobacco, a highly efficient green bioreactor for production of therapeutic proteins. Biotechnol Adv 28:214-221

Trouiller P, Olliaro P, Torreele E, Orbinski J, Laing R, Ford N (2002) Drug development for neglected diseases: a deficient market and a public-health policy failure. Lancet 359:2188-2194

Walmsley AM, Alvarez ML, Jin Y, Kirk DD, Lee SM, Pinkhasov J, Rigano MM, Arntzen CJ, Mason HS (2003) Expression of the B subunit of Escherichia coli heat-labile enterotoxin as a fusion protein in transgenic tomato. Plant Cell Rep 21:1020-1026

Webby RJ, Webster RG (2003) Are we ready for pandemic influenza? Science 302:1519-1522

Webster DE, Smith SD, Pickering RJ, Strugnell RA, Dry IB, Wesselingh SL (2006) Measles virus hemagglutinin protein expressed in transgenic lettuce induces neutralising antibodies in mice following mucosal vaccination. Vaccine 24:3538-3544

Webster DE, Wang L, Mulcair M, Ma C, Santi L, Mason HS, Wesselingh SL, Coppel RL (2009) Production and characterization of an orally immunogenic Plasmodium antigen in plants using a virus-based expression system. Plant Biotechnol J 7:846-855

Weir E, Hatch K (2004) Preventing cold chain failure: vaccine storage and handling. CMAJ 171:1050

Wirkas T, Toikilik S, Miller N, Morgan C, Clements CJ (2007) A vaccine cold chain freezing study in PNG highlights technology needs for hot climate countries. Vaccine 25:691-697

World Health Organization (2006) WHO strategic action plan for pandemic influenza. http://www.who.int/csr/resources/publica tions/influenza/WHO_CDS_EPR_GIP_2006_2/en/index.html

World Health Organization (2009) Pandemic influenza vaccine manufacturing process and timeline. http://www.who.int/csr/ disease/swineflu/notes/h1n1_vaccine_20090806/en/index.html

Zhang X, Buehner NA, Hutson AM, Estes MK, Mason HS (2006) Tomato is a highly effective vehicle for expression and oral immunization with Norwalk virus capsid protein. Plant Biotechnol J 4:419-432

Zoler ML (2009) H1N1 vaccine snags highlight limits of egg-based production. Elsevier Global Medical News. http://www.thelancet. com/H1N1-flu/egmn/0c03c6c6 